\title{
WATERFRONT DEVELOPMENT IN MALAYSIA: \\ DO WE HAVE SUSTAINABLE GOVERNANCE?
}

\author{
AZLINA BINTI MD YASSIN \\ University Tun Hussein Onn Malaysia
}

\section{SANDY BOND and JOHN McDONAGH \\ Lincoln University}

\section{ABSTRACT}

The waterfront is recognised as the zone of interaction between a city and a river. In Malaysia, waterfront developments were established when the country was first settled, mainly as a transport route and for trading. Waterfronts became more urbanised and commercialised from the early 1990's onwards. However, due to constraints such as ineffective governance as well as inadequate federal, state and municipal planning guidelines, the waterfronts have problems such as environmental degradation, crime and flooding. Although some waterfront development projects continue to remain profitable, with good public access, many do not.

This paper examines the effectiveness of governance for waterfront developments in Malaysia. The data presented in this paper was obtained from in-depth interviews with stakeholders involved in waterfront development projects in Malaysia; in particular, from three selected case study areas: Kuching Riverfront, Malacca Waterfront and Glenmarie Cove Riverfront. The interview results show that Malaysia does not have effective governance for waterfront developments for several reasons. A low level of cooperation between stakeholders involved in waterfront development projects was identified as a main contributor to the governance problems. These results will be used to provide information for developing guidelines for best practice for waterfront developments in Malaysia.

Keywords: Waterfront development, waterfront governance

\section{INTRODUCTION}

In Malaysia, rivers make a huge contribution of social importance to global transportation; as an element in cultures and traditions, as a source of primary and secondary production, and for biodiversity. A close association between Malaysia and water has been inherent since the beginning of civilisation and, in fact, settlements 
have historically sprung up along river banks, hence many urban cities in Malaysia, such as Kuala Lumpur, Terengganu and Malacca, were established after waterfront settlements developed near a water body of some type (Andaya \& Andaya, 2001; Weng, 2005). As a consequence, some villages are named after the rivers that run through them, namely: Sungai Rengit, Sungai Mati and Sungai Kapal in Johor (Yassin, Eves \& McDonagh, 2010a).

After gaining independence in 1957, population growth, economic growth, urbanisation and increased technology have transformed many Malaysian river systems from water industries into non-water industries. This transformation symbolised the independent city states' efforts to remake themselves for the $21^{\text {st }}$ century. At the same time, due to these changes, the function of the waterfront areas declined and subsequently, was abandoned.

After being abandoned for many years, Malaysia has begun to redevelop its waterfront areas and Kuching city in Sarawak was selected to initiate this project. This fully funded project by the State of Sarawak, named the Kuching Riverfront, was proposed in 1989 by the Chief Minister of Sarawak, was mainly for recreational purpose and was completed in 2003 (Sarawak Economic Development Corporation, 1990).

At present, many waterfront development projects have been undertaken throughout Malaysia, some have been successful developments while others have not been. In some cases, the implementation of these waterfront projects has been driven more by investment needs rather than for community and environmental needs. Moreover, inadequate regulations for the control of waterfront developments in this country, as well as ineffective governance (Yassin, Eves \& McDonagh, 2010b) has led Malaysia to suffer from environmental and social ill-effects.

This paper focuses on the respondents' views about governance for waterfront developments in Malaysia, in terms of their effectiveness for the control of waterfront developments in Malaysia. A qualitative method by way of case studies, with one-toone in-depth interviews and document reviews, was used to identify the relevant information about the governance of waterfront developments in Malaysia. The information gathered was then included in an effort to improve waterfront development practices for Malaysia in the future.

\section{REVIEW OF THE LITERATURE}

\section{Successful waterfront development}

Waterfront redevelopment has taken place around the world over the last three decades and has grown in popularity. Parallel with the growing popularity of waterfront redevelopment is the idea that it is essential to give full consideration and attention to several principles to maintain the public's interest in the waterfront area and to protect the waterfront itself. According to Torre (1989), the success of a 
waterfront development is only achieved once it can function on all levels and benefit all stakeholders. He expressed his view on successful waterfronts, as follows:

\begin{abstract}
"No matter how unique or exciting is a riverfront development, it can only be successful if it functions on all levels. From regional access and circulation to adequate parking capacity to ease and comfort of pedestrian movement to the visitors' overall experience, all levels must sequence successfully as well as meeting the capacities on peak activity days".
\end{abstract}

(p. 38)

Therefore, in order to achieve the specific aims of a successful waterfront development, Torre (1989) identifies several elements to be taken into consideration while planning a waterfront development, as presented in Table 1.

\title{
Table 1: Elements for a successful waterfront development
}

\section{Element Description}

Theme

"Theme" means a unifying idea, image or motif developed throughout a work (Concise Oxford English Dictionary, 2009). Significantly important to maintaining people's loyalty to a waterfront area.

Themes are designed in the initial stages, mainly to control future spatial analysis, land use materials, scale and meaning.

Determined after several considerations: climate, layout, design, land use of the development, project's culture and history.

Image

Image means a representation of an object (Concise Oxford English Dictionary, 2009). The implementation of the theme would create the image.

Image could give a perception of the future waterfront project and good images have become benchmarks for other projects.

Authenticity Authenticity, from the word authentic, means undisputed origin or genuine (Concise Oxford English Dictionary, 2009).

Maintaining authentic value of the waterfront area and the surrounding area is important for a successful waterfront project.

Function

Pedestrian access to a lively outdoor eating area and entertainment centre gives visitors the chance to enjoy the water 
environment along with convenient services for residential and working districts.

Public perception of need

Financial feasibility

Environmental approvals

Construction technology

Effective management

Beginning the project
The combination of theme, image, authenticity, environment and financial considerations should also include public consideration, to avoid environmental problems.

A waterfront is considered feasible once it is packaged, designed, promoted, managed and operated effectively.

The key fundamental is a waterfront concept that leads the financial assessment not the reverse.

Inter-agency meetings are required sequentially to determine the environmental impact of the waterfront development. Approval from various agencies is required.

As a rule of thumb every acre of impact needs two acres of mitigation and must be provided and for the most part, enhancement does not count.

Use cost-effective and environmental friendly materials for construction, pressure treated wood is recommended.

Proper management must include a number of different sources of expertise, and coordination between them is very important no matter whether for public or private waterfront development.

The combination of all the elements listed above will result in a comprehensive, balanced and self contained waterfront project. Updated current information about waterfront areas is needed.

Participation from all responsible groups, including the public, is important at every stage of development.

Organisational management: establish a waterfront committee and include representatives from the government authority to make the process effective.

Maintain momentum: create anticipation and marketing, and maintaining the momentum until the project is completed is important.

Plan an opening celebration: a celebration illustrates commitment to the development.

(Source: Torre, 1989) 
In addition, Bertsch (2008) determined that for any use of a waterfront area, a water plan should be developed before the land plan, to maintain an economically viable waterfront. Therefore, he recommended several principles that must be adhered to when developing plans for waterfront areas, as follows:

(1) Accessibility - the waterfront should not be isolated or separated from the development so the public can access the waterfront easily (convenient means for visitors to access the waterfront area).

(2) Integrated - integration of the history, culture and existing architecture are recommended for a new waterfront development.

(3) Sharing benefits - a balance between public benefit and developer profitability must be found. A public-private partnership is essential to realising the inspiration of the design.

(4) Stakeholder participation - the involvement of many interested parties is compulsory: government agencies, developers, community organisations, environmental groups and the public all have a stake in the development of a waterfront property and all must be involved in the process.

(5) Construction phase - breaking down a huge project into several phases and allowing all stakeholders and the general public to see this provides a vision of the future.

Thus, apparently, harmonies in waterfront development can be achieved through combinations of people, nature and technology (Mann, 1973).

\section{Principles for sustainable waterfront developments}

Waterfronts are one of the most valuable resources for the country - being limited, precious and non-renewable assets. To secure long-term growth of the resource, it is important for waterfront areas to be used strategically to maintain their economic value and to enhance their specific features or images (Bruttomesso, 2006). For this reason, Bruttomesso (2006) recommended ten (10) principles for securing excellence in waterfront redevelopment projects. The sustainable principles are presented in Table 2. 


\section{Table 2: Principles for sustainable waterfront development}

Ten principles for a sustainable waterfront development
- Secure the quality of the water and the environment.

- Waterfronts are part of the existing urban fabric.

- $\quad$ Character is given by the historic identity.

- $\quad$ Mixed-use is a priority.

- $\quad$ Public access is a prerequisite.

- $\quad$ Planning in public-private partnerships speeds the process.

- $\quad$ Public participation is an element of sustainability.

- Waterfronts are long term projects.

- $\quad$ Revitalisation is an ongoing process.

- Waterfronts profit from international networking.

(Source: Bruttomesso, 2006)

\section{Sustainable governance of waterfront development}

According to Martínez et al. (2007), approximately 41\% of the world's population live within 100 kilometres of water. In addition, Duxbury and Dickinson (2007) stated that between 1990 and 2000 the number of people moving to the water's edge increased from 2.0 to 2.3 billion and this number is forecast to increase up to about $34 \%$ by the year 2025. The increasing population growth at the waterfront has also increased pressure on the demand for supplies of clean water, as well as tourism, recreation and infrastructure development. Thus, this continued strain on waterfronts required a set of principles for governance be developed that will ensure their future sustainability. These are required to mitigate both for adverse impacts on the environment from human activities as well as the adverse impact of environmental changes on human populations.

An integrated waterfront management system is a process of governance that consists of the legal and institutional frameworks necessary to maximise the benefits provided by the water zone and to minimise the conflicts and negative effects of activities (Post \& Lundin, 1996). Such a system is seen as a comprehensive approach which, when considering all the sectoral activities that affect waterfront resources, does not exclude 
dealing with the economic, ecological, social and environmental issues. Therefore, through this management process, every stage of the waterfront development process (setting objectives, planning and implementation) should involve as wide a spectrum of interest groups as possible to balance the diverse uses of the waterfront.

In 1997, in response to the increasing pressure on the waterfront, six principles for the sustainable governance of waterfronts were developed incorporating various disciplines and stakeholder groups (Costanza et al., 1998; Costanza, Cumberland, Daly, Goodland, \& Norgaard, 1997); and is known as the Lisbon principles. ${ }^{1}$ Table 3 summarises the basic guidelines for administering the use of common natural and social resources. Incorporating all the principles is recommended to achieve sustainable waterfront development.

\section{Table 3: Principles of governance on natural and social resources}

\section{Principle}

Responsibility

Scale-matching

\section{Description}

Access to environmental resources carries attendant responsibilities to use them in an ecologically sustainable, economically efficient and socially fair manner.

Individual and corporate responsibilities and incentives should be aligned with each other and have broad social and ecological goals.

Ecological problems are rarely confined to a single scale.

Decision making on environmental resources should:

- $\quad$ Be assigned to institutional levels that minimise ecological input.

- Ensure the flow of ecological information between the different institutional levels.

- $\quad$ Take ownership and actors into account.

- $\quad$ Internalise costs and benefits.

Appropriate scales of governance will be those that have the most relevant information, can respond quickly and

\footnotetext{
${ }^{1}$ Lisbon principles were developed during a workshop held in Lisbon, Portugal, in $7-9^{\text {th }}$ July 1997, sponsored by the Independent World Commission on the Oceans (IWCO) in conjunction with the Luso - an American Development Foundation Outfit. Lisbon principles were designed following the Stockholm (1972) and Rio (1992) United Nation meetings - the need for a common outlook and for common principles to inspire and guide the peoples of the world in the preservation and enhancement of the human environment.
} 
efficiently, and are able to integrate across scale boundaries.

Precautions

In the face of uncertainty about potentially irreversible environmental impacts, decisions concerning their use should err on the side of caution.

The burden of proof should shift to those whose activities potentially damage the environment.

Adaptive

management

Full cost allocation

Participation
Given that some level of uncertainty always exists in environmental resource management, decision-makers should continuously gather and integrate appropriate ecological, social and economic information with the goal of adaptive improvement.

All internal and external costs and benefits, including social and ecological, of alternative decisions concerning the use of environmental resources should be identified and allocated. When appropriate, markets should be adjusted to reflect full costs.

All stakeholders should be engaged in the formulation and implementation of decisions concerning environmental resources.

Full stakeholder awareness and participation contributes to credible, accepted rules that identify and assign the corresponding responsibilities appropriately.

(Source: Costanza et al., 1997)

However, these core six principles were not limited to waterfront resources but included all environmental resources. Therefore, taking the Lisbon principles as guidance, Duxbury and Dickinson (2007) recommended principles for the sustainable governance of the waterfront - particularly the principles highlighting the waterfront issue, such as coastal disasters. Table 4 presents the principles for sustainable governance of the waterfront. 
Principle

Sustainability

Adaptive

Management

Participation

Integration

\section{Description}

The use of natural capital within the water boundary should be sustainable and achieved in an efficient and socially equitable manner.

Decision makers should have the ability to integrate ecological, social and economic information and to have the flexibility to cope with changes in the environment.

Stakeholder participation is vital in the decision making process about environmental resources.

Decision making should integrate policy with input from the scientific community.

(Source: Duxbury \& Dickinson, 2007)

Clear and coherent principles and/or policies are the main challenges for the development of cities in order to them to be sustainable. The implementation and aims of the interventions should not be contradictory (Yossi \& Sajor, 2006). However, this requires more effort particularly in relation to the management of budgets and time of the government officials. Therefore, in making more integrative approaches, participation by relevant stakeholders such as external experts, non-governmental organisations and community based organisations is encouraged and helps to address the limitations of government institutions.

In addition, Yossi and Sajor (2006) agree that good collaboration and coordination between different government authorities and external stakeholders (as mentioned above) is important for waterfront development projects. This also needs the willingness of cross-boundary government authorities to make a commitment to work together in the planning and development process. Moreover, the willingness of the government to include public participation (i.e. the waterfront community) in the development process would maximise the benefits of waterfront developments.

\section{Governance for waterfront development in Malaysia}

Governance is about local change and reform to solve certain issues. According to Elfithri et al. (2008), effective governance requires changing and reforming some laws and regulations. Due to different political, social, economic and administrative systems that are in place to develop and manage natural resources such as land resources, the balance of power and administration of a country is important. In practice, the governance and administration of natural resources in Malaysia involves several departments and agencies that operate dependently, or independently, of one another according to the specific responsibilities assigned to them. Thus, this requires the participation and involvement from stakeholders within a large context of shared 
understanding (Mokhtar \& Elfithri, 2005) and would result in effective governance. In addition, Elfithri et al. (2008) noted that successful governance could be achieved by considering decision-making power, resources and capacity at the lower levels of management.

Water bodies and land are the two main resources directly associated with waterfront development. In Malaysia, natural resources - land, water, rivers and forest - are under the jurisdiction of the State Government (Federal Constitution, 2006). In addition, the State Government also has full responsibility for water management including gazetting and preserving water catchments, development along the river corridors, urban development and logging forest timber. Also, these natural resources provide revenue to the State Government through their uses - timber logging, industrial, township development and water supply (Abidin, 2004). Nevertheless, when it comes to natural resource development matters, both governments (Federal and State) are involved. In fact, in Malaysia, involvement from both parties is required in management and administration activities, where each of them has their specific tasks in planning, land-use control and management (Welch \& Keat, 1987). The specific tasks assigned to them concern a wide range of aspects including political, social, economic and administrative systems. Figure 1 shows the administration and government institutions that participate in water and land matters in Malaysia, and Table 5 summaries the objectives and functions of each institution.

\section{Table 5: Objectives of the institutions involved in waterfront development in} Malaysia

Institution Objectives

Ministry of Natural

Resources and

Environment

(MONRE)
To ensure well balanced management of natural resources and environment in achieving sustainable development.

To ensure an efficient and effective service delivery system of natural resources and environment management.

To ensure an efficient and effective implementation of development projects.

To establish training and research and development (R\&D) as an innovative exploration catalyst in natural resources management and environmental conservation.

To ensure a clean, safe, healthy, productive and unpolluted environment

Department of

Irrigation and

To ensure that formulation of policies, strategies and programs are based on the Cabinet and Natural Resource Drainage, MONRE and Environments, top management decisions while 
Department of Mineral and Geosciences, MONRE
Department of

Forestry of Peninsular

Malaysia and

Department of Wild

Life and National

Park, Peninsular

Malaysia, MONRE
Department of

Environment, MONRE implementing action based on current needs.

To ensure that implementation of policies, strategies and programmes are monitored efficiently and effectively.

To ensure that all matters related to cabinet papers, concept papers, reports and relevant documents are properly prepared and updated.

To ensure that Parliament's functions are managed according to the standard procedures.

To ensure that planned project developments will have a positive impact on the nation's development.

To ensure that monitoring of project development is done consistently.

To plan and set policies and directions for the development and enhancement of the mineral and geoscience sector.

To ensure that policies and legislation related to the development of minerals and geo-science is always relevant and contributes to the development of the industry and economic progress, and is implemented in an environmentally friendly manner.

To ensure advancement in the forestry sector by conservation and development of the forest area and to achieve sustainable forest management objective for the conservation of environmental stability.

To protect, manage and preserve biodiversity for the production of optimum benefits.

To protect and develop protected areas for the purpose of research, education, economic, aesthetic, recreation and ecological purposes.

To enhance knowledge, awareness and public support on the importance of biodiversity conservation.

To establish a holistic policy framework to ensure a healthy, clean, safe and productive environment so as to achieve sustainable development. This division is also responsible for ensuring that the country's interests in global and regional environmental issues are protected. 
Department of

Director General of

Lands and Mines and

Department of Survey

and Mapping,

Malaysia, MONRE
To ensure that the implementation of land administration in the country and the provision of survey and mapping services are in line with current government policy.

To enable the National Land Council to function as an effective forum to ensure the uniformity and consistency of land administration in the country.

(Source: Malaysian Department of Drainage and Irrigation, 2009)

Figure 1: Institutional framework for land and water resource development in Malaysia

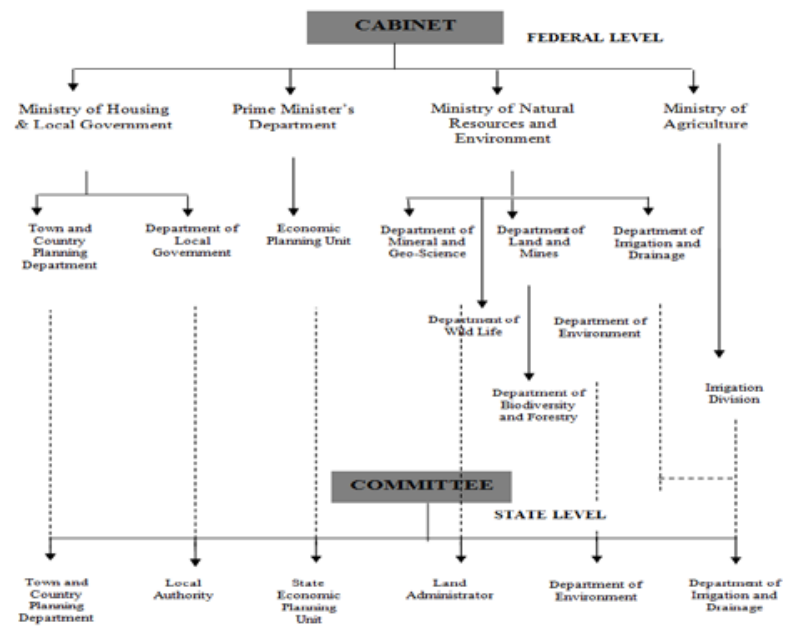

Source: Malaysian Department of Drainage and Irrigation, 2009

\section{RESEARCH METHODS}

A qualitative approach was employed in this study. The significance of the qualitative approach, in general, was to explore new phenomena and to understand complexities that focused on the provision of in-depth information. The emphasis of the case study approach in relation to this study was to examine governance in waterfront developments from the waterfront development stakeholder's point of view, as well as to identify the constraints for governing waterfront developments. Use of the case study approach was because very little information was known about the situation and little information was available from similar issues in the past. The case study approach was completed through the collection of several sources of evidence, such as interviews and document reviews (Eisenhardt, 1989, p. 534; Yin, 1984, p. 23). 
Multiple case studies were employed in the research. Using multiple case studies in this study provided more confidence in the overall results. Consistent findings developed over the investigation of more than one case study gave more robust findings (Yin, 1993, 1994) . A key requirement in the selection of case study areas was their status as a waterfront development project area. The other selection criteria for case studies were, as follows:

(1) Waterfront area - development at the front of a river.

(2) Type of waterfront project - recreational and residential.

(3) Willingness of all parties involved in the development to be personally interviewed.

(4) Availability of documents related to the development projects undertaken.

(5) Project reputation - successful waterfront development projects.

(6) Variability in regard to respondents involved in each case study area (i.e. level of experience).

Selection and investigation of a number of waterfront development projects enhanced the accuracy, validity and reliability of the results by capturing the holistic essence of the subject studied. A brief description of each case study area is presented in Table 6.

Table 6: Characteristics of the case study areas

$\begin{array}{cccc}\text { Case study area } & \begin{array}{c}\text { Kuching } \\ \text { waterfront }\end{array} & \begin{array}{c}\text { Malacca } \\ \text { waterfront }\end{array} & \begin{array}{c}\text { Glenmarie } \\ \text { riverfront cove }\end{array}\end{array}$

Feature

\begin{tabular}{lccc}
\hline $\begin{array}{l}\text { Name of water } \\
\text { body } \\
\text { Type of project }\end{array}$ & Sarawak river & Malacca river & Langat river \\
Project's Owner & Recreational & Recreational & Residential \\
Amenities & $\begin{array}{c}\text { State of Sarawak } \\
\text { Restaurants, river } \\
\text { access, shops, } \\
\text { waterfront } \\
\text { settlements. }\end{array}$ & $\begin{array}{c}\text { State of Malacca } \\
\text { River access, } \\
\text { shops, waterfront } \\
\text { settlements. }\end{array}$ & $\begin{array}{c}\text { DRB-HICOM } \\
\text { Restaurants, } \\
\text { housing, river } \\
\text { access. }\end{array}$ \\
Views & $\begin{array}{c}\text { River views and } \\
\text { city }\end{array}$ & River views and & city. \\
Proximity to river & $50 \mathrm{~m}$ & $50 \mathrm{~m}$ & $\begin{array}{c}\text { views. } \\
100 \mathrm{~m}\end{array}$ \\
Proximity to CBD & $1 \mathrm{~km}$ & $1 \mathrm{~km}$ & $35 \mathrm{~km}$
\end{tabular}


A judgemental sampling method was adopted for the sampling procedure for selecting respondents for interviews for this study. This was because the primary consideration in judgemental sampling was the judgement of who can provide the best information in order to fulfil the objectives of the research. The researcher only went to those people who were likely to have the required information and knowledge and the willingness to share it (Kitchin \& Tate, 2000). All respondents were included to aid a better understanding of waterfront developments in Malaysia, especially in relation to the governance of waterfront developments.

\section{RESULTS AND DISCUSSION}

\section{Response rate}

Interviews were sufficiently answered to allow a response rate of $100 \%$ to be obtained. A total of 25 face-to-face interviews were conducted within the 10 weeks from the $10^{\text {th }}$ of May to the $20^{\text {th }}$ of July, 2009. The interviewees were selected from the case study areas namely: Kuching Riverfront in Sarawak, Malacca Waterfront in Malacca and Glenmarie Cove Riverfront in Selangor. Input was obtained from three different sources; (i) Federal, State and Local Governments; (ii) Private sector; and (iii) waterfront community. Figure 2 summarises information about the interviewees participating in the interviews.

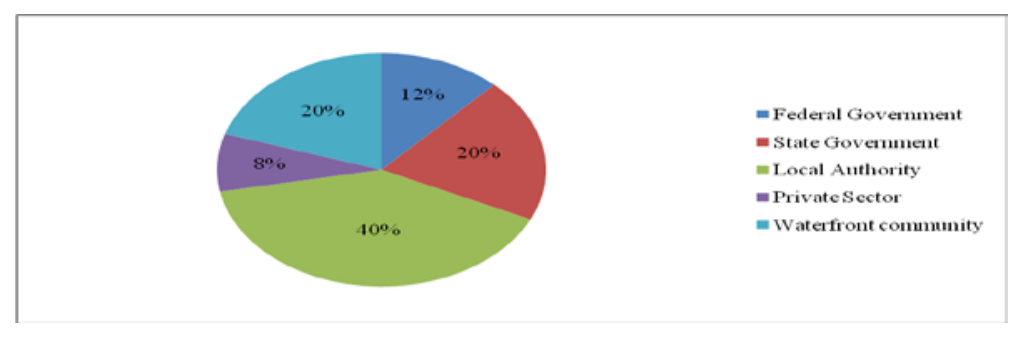

\section{The waterfront development process in Malaysia}

During the interviews, 20 respondents who were government officers (Federal, State and Local Government), as well as developers were asked several interview questions related to the waterfront development process in Malaysia.

Q: $\quad$ Does the waterfront development process differ from the general development process?

From the interviews, it appeared that the majority (85\%) of interviewees felt that waterfront development in Malaysia required a similar process as other forms of development, and that the government had full responsibility for the development starting from planning approval right up to completion. About 15\% of respondents felt that in some cases approval from other departments such as the Museum Corporation 
or the Department of Wild Life was required; for example, if the development included preservation areas.

Practically, the One-stop-centre (OSC) was responsible for facilitating and standardising the land development process in Peninsular Malaysia. Land development in the state of Sarawak was controlled by the State Planning Authority (SPA), ${ }^{2}$ and the Local Authority (the Council of the City of Kuching South and Kuching North City Hall) which did not get involved directly with the development process unless the development was proposed by them and used their allocated budgets.

Therefore, land development in Malaysia including waterfront projects, was required to follow similar processes imposed at each stage of development. Importantly, developments must meet the guidelines, as recommended by the land use planning guidelines. $^{3}$

\title{
Parties involved in waterfront development in Malaysia
}

The development process for waterfronts in Malaysia has similar processes imposed on it as other forms of development. In order to have an idea about parties involved in the waterfront development process, the following interview question was asked of the 20 respondents who were government officers (Federal, State and Local Government) and who were from the private sector.

Q: $\quad$ Any development usually involves many parties which are integrated into the development process. How about waterfront developments in Malaysia?

From the interviews, all respondents (100\%) thought that waterfront developments followed the same processes, involved the same officers and sometimes shared the same problems as other types of developments. Moreover, one of the interviewees thought that for development projects which were proposed by the Federal government, the State and Local Governments acted as the implementing agencies for the proposed project. He shared his opinion, as follows:

\begin{abstract}
"A government body has been involved for private and government projects from the beginning stage to the planning approval, no matter whether the project is funded by government and/or private sector. The contractor, who is normally a private contractor, is appointed in the implementation
\end{abstract}

\footnotetext{
${ }^{2}$ Under the Land Code (Amendment) Ordinance 1997, the committee consists of the Chief Minister, The State Planning Authority, with the Minister as Chairman, the Permanent Secretary to the Ministry of Planning Management, as the Secretary of the State Planning Authority, the Director of Lands and Survey Department, and three Ministers from different ministries.

${ }^{3}$ Land use planning guidelines are the systematic assessment of land and water potential, alternatives for land use and economic and social conditions, in order to select and adopt the best land use options. Its purpose is to select and put into practice those land uses that will best meet the needs of the people while safeguarding resources for the future (Soil Resources Management and Conservation Service, 1993).
} 
stage and local people do not participate” (Original

transcription).

(Interviewee G7)

In addition, from the interviews, it appears that in most cases, no involvement from public parties or the public is required if the proposed development involves public land acquisition. Table 7 presents parties involved for the selected case study areas.

\section{Table 7: Waterfront development projects - parties involved}

\section{Project \\ Party involved}

\begin{tabular}{ll}
\hline & Land owner: Sarawak State Government - (Government) \\
& Financial institution: Sarawak State Government - (Government) \\
Kuching & Developer: Sarawak Economic Development Corporation (SEDC) - \\
riverfront & (Government subsidiary) \\
& Consultants: \\
& $-\quad$ Conybeare Morrison \& Partners (Australia) - (Private) \\
& $-\quad$ United Consultants (Malaysia) - (Private) \\
& Contractor: PPES Bena Sdn. Bhd. \& Utraco (M) Sdn. Bhd. - (Private)
\end{tabular}

Malacca

Land owner: Malacca State Government - (Government)

waterfront

Financial institution:

- $\quad$ Ministry of Tourism ( $1^{\text {st }}$ phase $)$, Ministry of Natural Resources

\& Environment $\left(2^{\text {nd }}-4^{\text {th }}\right.$ phase $)$ - (Government)

- $\quad$ Malacca State Government - (Government)

Developer: Malacca State Government - (Government)

Contractor:

- $\quad$ Pembinaan Kaleigh Sdn Bhd \& Pesona Metro Sdn. Bhd. (Joint Venture).

- $\quad$ Kejuruteraan Asas Jaya Sdn. Bhd. ( $4^{\text {th }}$ phase) - (Private)

Glenmarie cove Land owner: Glenmarie Cove Development Sdn. Bhd. - (Private)

riverfront

Financial institution: Glenmarie Cove Development Sdn.Bhd - (Private)

Developer: Glenmarie Cove Development Sdn. Bhd. - (Private)

Consultants: Arah Rancang Sdn. Bhd. - (Private)

Contractor: Glenmarie Cove Development Sdn. Bhd. - (Private)

Source: Glenmarie Cove Development Sdn. Bhd., 2009; Sarawak Economic Development Corporation, 1990; State Government of Malacca, 2009 


\section{Governance in waterfront development in Malaysia}

In Malaysia, management and administration of natural resources involved several departments and agencies that operated dependently or independently of one another according to the specific responsibilities assigned to them (Rogers \& Hall, 2003).

All 25 respondents were asked their opinions about the management and administration of waterfront resources in Malaysia. The interview question about the governance of waterfront development in Malaysia was as follows:

Q: $\quad$ How does Malaysia practice governance for waterfront projects? Please comment.

From the interviews, it appears that more than half (60\%) of the respondents answered the question, while the rest (about $40 \%$ ) gave no response. This is possibly because governance is considered a sensitive issue and their responses could have reflected on their organisational image as well as on other organisations.

From the $60 \%$ of respondents who answered to the interview question, almost all (93\%) thought that the management and administration of waterfront resources was not effective, even though Malaysia has well structured management and administration of natural resources, including waterfront resources. Only one respondent answered positively, as follows:

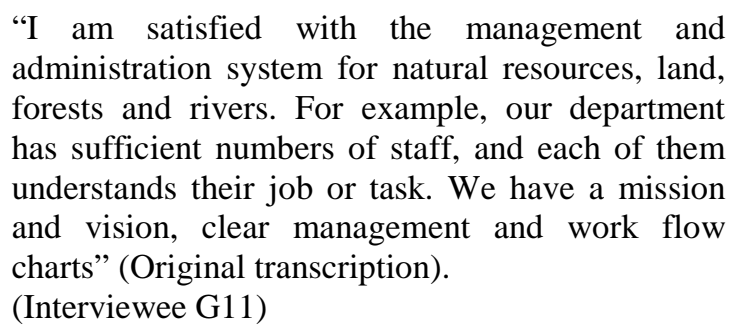

The 13 respondents who answered that there is ineffective governance for waterfront development in Malaysia, were further asked for reasons that constrain the delivery of effective governance in managing waterfront resources and waterfront development in Malaysia.

Q: $\quad$ In your opinion, what are the reasons that constrain effective administration and management for waterfront resources and waterfront development in Malaysia?

All 13 respondents (100\%) answered the question and most of them thought that low levels of cooperation between stakeholders was the main reason that contributed to ineffective governance for waterfront development in Malaysia, accounting for $46.1 \%$ of responses. The second reason identified for ineffective governance of waterfront developments was inefficient communication systems (38.5\%). Only a few 
respondents $(7.7 \%)$ thought that conflicts of interest were a reason for being unable to manage waterfront developments and waterfront resources effectively. Table 8 presents several reasons identified for the ineffective governance of waterfront developments in Malaysia.

\section{Table 8: Reasons for ineffective governance for waterfront developments}

\begin{tabular}{lcc}
\hline \multicolumn{1}{c}{ Factor } & Frequency $(\mathbf{n}=\mathbf{1 4})$ & Percent \\
\hline Low levels of cooperation between & 6 & 46.1 \\
stakeholders & 5 & 38.5 \\
Inefficient communication systems & 4 & 30.8 \\
Low enforcement on regulation & 3 & 23.1 \\
Inadequate policy / guidelines & 3 & 23.1 \\
Lack of expertise & 2 & 15.4 \\
External party interference & 1 & 7.7 \\
Conflicts of interest & & \\
\hline
\end{tabular}

Indeed, less participation and low collaboration among parties involved in the waterfront development was identified as a main cause of ineffective management of waterfront developments in Malaysia. These results are similar as stated by the Kuala Lumpur Structure Plan (1984); there are three reasons of government failure to improve environmental quality: (1) a lack of manpower and technical expertise; (ii) development approached that prioritised economic and engineering feasibility; and (iii) a low priority in the allocation of funds for landscaping and beautification programmes. Therefore, in order to achieve sustainable waterfront developments, support from the appropriate parties such as developers and the public was required, and efficient delivery systems with updated information were needed from each agency responsible (Bertsch, 2008; Duxbury \& Dickinson, 2007; Torre, 1989).

\section{CONCLUSION}

This paper explored the governance role in terms of waterfront development practices in Malaysia. From the results, it can be concluded that the waterfront development process in Malaysia followed a similar process to other kinds of development. Low levels of cooperation between stakeholders involved in the waterfront development process such as government officers and developer and inefficient communication systems among them, has resulted in unsuccessful waterfront developments. Moreover, low enforcement of existing regulations associated with land and waterfront developments and inadequate regulations specifically designed to control waterfront developments, caused further environmental problems. Thus, to achieve sustainable waterfront developments, sustainable governance was recommended as well as better enforcement of the regulations. For governance to be effective, participation should be inclusive with good communications so as to enhance transparency throughout the process. The attributes for the sustainable governance of 
waterfronts should be used with modification to suit the conditions in the local environment.

\section{REFERENCES}

Abidin, R. Z. R. Z. (2004). Water resources management in Malaysia: The way forward. Paper presented at the Asia Water 2004 (30 March - 02 April 2004).

Andaya, B. W., \& Andaya, L. Y. (2001). A history of Malaysia (Second ed.). Hampshire, Britain: Palsgrave.

Bertsch, H. (2008). The key elements to successful waterfront design. Real Estate Weekly, 54.39.

Bruttomesso, R. (2006). Waterfront development: A strategic choice for cities on water. Paper presented at the Waterfront Development Forum: China Maritime (02 March 2006), Hong Kong.

Concise Oxford English Dictionary (Ed.). (2009). (11 ed.). Oxford: Oxford University Press.

Costanza, R., Andrade, F., Antunes, P., Belt, M. V. D., Boersma, D., Boesch, D. F., et al. (1998). Principles for sustainable governance of the oceans. Science, 281, 198-199.

Costanza, R., Cumberland, J. H., Daly, H., Goodland, R., \& Norgaard, R. B. (1997). An Introduction to Ecological Economics. In R. Costanza (Ed.), Lisbon Principles of Sustainable Governance. Florida: St. Lucie Press.

Duxbury, J., \& Dickinson, S. (2007). Principles for sustainable governance of the coastal zone: In the contex of coastal disasters. Ecological Economics, 63, 319-330.

Eisenhardt, K. M. (1989). Building theories from case study research. Academy of Management, 14(4), 532.

Elfithri, R., Mokhtar, M., Shah, A. H. H., \& Idrus, S. (2008). Collaborative decision making within the context of integrated water resources management in Langat River Basin, Malaysia. Paper presented at the 7th World Wide Workshop for Young Environmental Scientist 2008 (13-16 May 2008), Créteil - France.

Federal Constitution. (2006). Laws of Malaysia. Malaysia: Constitution of Malaysia.

Glenmarie Cove Development Sdn. Bhd. (2009). Proposal of development - Report. Glenmarie Cove Development Sdn. Bhd. 
Kitchin, R., \& Tate, N. J. (2000). Conducting research in human geography: Theory, methodology and practice. Harlow: Prentice Hall.

Kuala Lumpur Structure Plan. (1984). Kuala Lumpur, Malaysia: Kuala Lumpur Planning and Building Control Department, Kuala Lumpur City Hall.

Malaysian Department of Drainage and Irrigation. (2009). River management activities. Kuala Lumpur, Malaysia: Department of Drainage and Irrigation, Ministry of Natural Resources and Environment.

Mann, R. (Ed.). (1973). Rivers in the city. Newton Abbot: David \& Charles.

Martinez, M. L., Intralawan, A., Vazquez, G., Perez-Maqueoa, O., Sutton, P., \& Landgrave, R. (2007). The coasts of our world: Ecological, economic and social importance. Ecological Economics of Coastal Disaster - Coastal Disasters Special Edition, 63(2-3), 254-272.

Mokhtar, M., \& Elfithri, R. (2005). Participatory management for integrated water resources management through collaborative decision making. Paper presented at the IWRM consultation for senior executive in the public sector.

Post, J. C., \& Lundin, C. G. (1996). Guidelines for integrated coastal zone management. Washington D.C., U.S.A: The International.

Rogers, P., \& Hall, A. W. (2003). Effective Water Governance. Stockholm: Global Water Partnership (TEC Background Papers No.7).

Sarawak Economic Development Corporation. (1990). Kuching Riverfront Master Plan. Sarawak, Malaysia: Sarawak Economic Development Corporation.

Soil Resources Management and Conservation Service. (1993). Guidelines for Land Use-Planning. Rome, Italy: Food and Agriculture Organization of the United Nation.

State Government of Malacca. (2009). Fact sheet - Malacca Waterfront. State Government of Malacca.

Torre, L. A. (1989). Waterfront development. New York: Van Nostrand Reinhold.

Welch, D. N., \& Keat, L. T. (1987). Water Resources Development and Management in Malaysia. In Water Resources Policy for Asia. Rotterdam, Netherlands: A. A. Balkema.

Weng, C. N. (2005). Sustainable management of rivers in Malaysia - Involving all stakeholders. International Journal River Basin Management, 3(3), 147-162. 
Yassin, A. M., Eves, C., \& McDonagh, J. (2010a). An evolution of waterfront development in Malaysia. Paper presented at the $16^{\text {th }}$ Pacific Rim Real Estate Society Conference (24-27 January 2010), Intercontinental Hotel, Wellington, New Zealand.

Yassin, A. M., Eves, C., \& McDonagh, J. (2010b). Waterfront development in Malaysia: Do we have sustainable governance? . Paper presented at the $\mathrm{PhD}$. Colloqium Program for $16^{\text {th }}$ Pacific Rim Real Estate Society Conference (24-27 January 2010) Intercontinental Hotel, Wellington, New Zealand.

Yin, R. K. (1984). Case study research: Design and methods. Beverly Hills, California: SAGE Publications.

Yin, R. K. (1993). Application of case study research. California: SAGE Publication.

Yin, R. K. (1994). Case study research: Design and methods (2 ed.). Beverly Hills, CA: SAGE Publishing.

Yossi, B., \& Sajor, E. E. (2006). Development of riverside kampung and management of rivers in Yogjakarta Indonesia: Issue of policy coherence and relevance of socio economic characteristics of river bank communities Paper presented at the Regional Conference on Urban Water and Sanitation in Southest Asean Cities, Vientiane, Lao PDR.

\section{Email contact: azlina@uthm.edu.my}

